\title{
Halal Tourism as a Means of Empowering the People's Economy
}

\author{
Fathan Budiman $^{1^{*}}$, M. Mustahal ${ }^{2}$, Abdul Basit ${ }^{3}$ \\ ${ }^{1}$ Doctoral Program at UIN Prof. K.H. Saifuddin Zubri Purwokerto, ${ }^{2}$ STAI An \\ Nawawi Purworejo, ${ }^{3}$ UIN Prof. K.H. Saifuddin Zubri Purwokerto \\ Corresponding Authors: $1^{*}$ fathanbudiman22@gmail.com, \\ ${ }^{2}$ mustahal_muhamad@yahoo.com, ${ }^{3}$ abdulbasit1969@gmail.com
}

Article History:

Submit:

2021-12-29

Publish:

2022-02-28
Abstract

This study aims to explain the economic empowerment of the people based on halal tourism based on the Qur'an. The large number of global Muslim tourists visiting Indonesia, makes halal tourism potential to be one of the sectors driving Indonesia's halal industry. There are no less than 140 million Muslim tourists with online shopping of USD 35 billion every year. This is a challenge as well as an opportunity to make halal tourism a national tourism industry and a means of empowering the people's economy. This study used descriptive qualitative method. The results of the study indicate that the development of halal tourism can be used as a means to empower the people's economy. Opening up greater job opportunities thereby reducing unemployment. Improving the welfare of the people by opening up business and job opportunities. Can increase the income of the people so that it has an impact on increasing the ability of the community to be able to live more prosperously.

Keywords: Economy; Empowerment; Halal; Tourism 
Journal Homepage http://ijssr.net/index.php/ijssr

This is an Open Access article under the CC BY SA license

$\begin{array}{ll}\text { Published by } & \text { https://creativecommons.org/licenses/by-sa/4.0/ } \\ \text { Indonesian Academy of Social and Religious Research }\end{array}$

\section{Introduction}

Economic empowerment of the people seeks to improve the quality of life based on the strengths possessed by the community and the individual itself. The economic empowerment of the people through halal tourism is expected to provide an economic contribution to the local community in improving social life. In addition to local communities benefiting from tourist arrivals, they can also maintain and maintain local culture and nature conservation in their area, because that is the main capital of local communities. ${ }^{1}$

Community empowerment through halal tourism is expected to contribute to the economy, either directly or indirectly, to the local community and improve social life. In addition to local communities benefiting from tourist arrivals, they can also simultaneously maintain and maintain local culture and nature conservation in their area, because that is the main capital of the local community. ${ }^{2}$

Religious motivations and halal tourism have become widespread and popular in recent decades, occupy an important segment of international tourism and have grown substantially in recent years. Religious tourism is one form of tourism that is less studied in tourism research. ${ }^{3}$ The consistent growth in this market segment has become a global trend in the tourism industry.

The trend of religious travel is not a new phenomenon. Religious tourism has long been an integral motif and is usually considered the oldest form of economic travel. Every year millions of people travel to major pilgrimage destinations around the world. It is estimated that nearly 240 million people per year make pilgrimages, both from Christians, Muslims and Hindus. Religious tourism has become synonymous with the growth of tourism in modern times. ${ }^{4}$

1 Abrista Devi and Irman Firmansyah, "Developing Halal Travel and Halal Tourism to Promote Economic Growth: A Confirmatory Analysis," Journal of Islamic Monetary Economics and Finance 5, no. 1 (2019): 193-214.

2 Aripin Marpaung, "Increasing Economic Empowerment of the People through Productive Waqf," Britain International of Humanities and Social Sciences (BIoHS) Journal 2, no. 3 (2020): 632-642.

3 Alfonso Vargas-Sánchez and María Moral-Moral, "Halal Tourism, Where Are We?," 2018, 211-232.

4 Dallen J Timothy and Daniel H Olsen, Tourism, Religion and Spiritual Journeys, vol. 4 (Routledge London, 2006). 
Indonesia as a country with religious and cultural diversity has a historical and traditional heritage that cannot be separated from the religious aspects and religious practices of the community. Cultural and religious heritage with a diversity of races, ethnicities, languages and customs is a potential for tourism development. In particular, Muslims as the majority of people in Indonesia certainly have unique characteristics that characterize the nation with existing tourist destinations, such as palaces, mosques, heirlooms, tombs, to culinary delights. ${ }^{5}$

The polarization of Muslim culture and religious practices attracted tourists to visit the country which became known as religious tourism. The term religious tourism is growing in line with the development of the global Islamic economy, then the term tourism has changed to sharia tourism and in recent years the term has shifted again to halal tourism. ${ }^{6}$

The development of sharia or halal tourism is an alternative to industrial tourism in Indonesia in line with the trend of the halal tourism industry as part of the global Islamic economy. The large potential number of global Muslim tourists visiting Indonesia makes halal tourism one of the sectors driving the Indonesian halal industry. In 2018, there were 140 million Muslim tourists with online shopping of USD 35 billion, and in 2020 it is projected to reach 158 million people. ${ }^{7}$ In addition, in 2019 Indonesia and Malaysia took the top positions in the countries with the best halal tourist destinations. ${ }^{8}$

This study on halal tourism is to explore the meaning of integrated cultural tourism, as a spiritual experience of modern society, becoming a religious tradition that has lasted for a long time in line with the historical development of Indonesian society. However, this context will be different if it is related to the tourism sector as part of industrial or business activities that can provide economic benefits and is projected in government policies to improve people's welfare.

This paper will describe several concepts related to halal tourism which is a

5 Noga Collins-Kreiner and Geoffrey Wall, "Tourism and Religion: Spiritual Journeys and Their Consequences," in The Changing World Religion Map: Sacred Places, Identities, Practices and Politics, 2015, 689-707.

6 Dini Mariska and Eric Jacob Shelton, "Prophet or Profit? Emotional Reflections on Indonesian Tourism," 2018, 271-288.2006: 1

7 Xiong Jia and Zhang Chaozhi, "Halal Tourism': Is It the Same Trend in Non-Islamic Destinations with Islamic Destinations?," Asia Pacific Journal of Tourism Research 25, no. 2 (2020): 189-204.

8 Hadi Peristiwo, "Indonesian and Malaysian Potential for a Halal Tourism Industry," African Journal of Hospitality, Tourism and Leisure 9, no. 1 (2020): 1-16. 
global Islamic economic trend. This study will also explore how the development of halal tourism can be used as a way of empowering the people's economy. The study of halal tourism is included in the latest study which has become the focus of researchers and practitioners of the travel business in Indonesia. Although it has been practiced for a long time, the facts show that the phenomenon of halal tourism in Indonesia can be further optimized to be introduced as a world halal tourism center.

\section{Literature Review}

The research of Ima Rahmawati Sushanti, Mustamine H. Idris, Baiq Harly Widayanti, Fariz Primadi Hirsan, Lukman Abdullah, Intan Savia Fitri (2018) concluded, local economic empowerment can be developed with halal food initiatives, improving infrastructure, enriching halal activities, and improving services. traveler. ${ }^{9}$

Eva Siti Ropiah's research (2018) shows the economic potential of halal tourism in Cirebon Regency can be seen from pilgrimage, culinary and cultural tourism which can continue to be developed into a lucrative economic potential especially with the support of the government and other elements such as academics and practitioners. ${ }^{10}$

\footnotetext{
9 Maryam Taha Mannaa, "Halal Food in the Tourist Destination and Its Importance for Muslim Travellers," Current Issues in Tourism 23, no. 17 (2020): 2195-2206.travel experience satisfaction and retention among Muslim travellers. The study adopted the qualitative approach. Required data were collected through 35 semi-structured interviews. The study revealed that the availability of halal food neither has a significant impact on Muslim travellers $\backslash u 2019$ destination selection decision nor on the overall travellerslu2019 satisfaction. However, the study findings indicated that availability of halal food affects the travellerslu2019 intentions to revisit the destination, length of stay and the type of accommodation chosen. The study findings are valuable for the hospitality industry managers and providers to understand the importance of halal food for Muslim travellers. The findings also help the Destination Management Organizations to better promote and serve products to Muslim travellers and increase the non-Muslimslu2019 awareness of halal principles and related food products.", "author" : [ \{ "dropping-particle" : ", "family" : "Mannaa", "given” : "Maryam Taha”, "non-droppingparticle" : "”, "parse-names" : false, "suffix" : "” \} ], "container-title" : "Current Issues in Tourism”, "id”: "ITEM-1", "issue" : "17", "issued" : ‘ "date-parts" : [ [ "2020"] ] \}, "page": "2195-2206", "title": "Halal food in the tourist destination and its importance for Muslim travellers", "type" : "article-journal", "volume": "23"], "uris" : [ "http://www.mendeley.com/documents/?uuid=86908794-ec81-4bbf-9a0674d1f998bef1"] \} ], "mendeley" : \{ "formattedCitation": "Maryam Taha Mannaa, \u201cHalal Food in the Tourist Destination and Its Importance for Muslim Travellers, lu201d <i>Current Issues in Tourism</i> 23, no. 17 (2020

${ }^{10}$ Ima Rahmawati Sushanti et al., "An Assessment of Local Economic Empowerment Using Halal Tourism Approach: A Case from Sembalun District East Lombok, Indonesia," IJECA (International Journal of Education and Curriculum Application) (2018): 112.
} 
The results of research by Soraya Ratna Pratiwi, Susanne Dida, Nuryah Asri Sjafirah (2018) show that halal tourism in the city of Bandung is developed through support from various cross-institutions, which is called the penta helix strategy. The communication strategy carried out by the Department of Tourism and Culture of West Java Province by conducting socialization to raise awareness to the related SKPD. A more complex communication strategy is needed to communicate halal tourism to stakeholders and the community. ${ }^{11}$

Desi Maulida's research (2019) shows that the strategy carried out by the Culture and Tourism Office with the Aceh branding team has been going well, especially in marketing communication activities. This is indicated by the many programs related to the implementation of marketing, both using print media, electronic media, billboards, and internet media, especially social media. However, in branding activities, there are actually several obstacles that must be faced, such as industry players who are less cooperative to provide halal certification as a prerequisite for halal tourism, lack of budget allocation, and low awareness of public participation. ${ }^{12}$

In 2020 Mutiaralinda Sartika Nasution, Basuki Prayitno, and Ihsan Rois researched the development of halal tourism for the welfare of the people in the city of Mataram. The results of this study indicate that the development of halal tourism carried out by the Mataram City Government is quite good. The various efforts to develop tourist destinations that have been carried out by the Mataram city government have an impact on improving the welfare of the people of Mataram City, which is illustrated by the increase in the HDI index from year to year. ${ }^{13}$

Abrista Devi and Irman Firmansyah (2019) researched "Developing Halal Travel And Halal Tourism To Promote Economic Growth: A Confirmatory Analysis". The results of this study indicate that to develop tourism, it is necessary to develop the halal marketing sector, halal travel and tourism, and halal products. These tourism development efforts must be initiated and supported

11 Soraya Ratna Pratiwi, Susanne Dida, and Nuryah Asri Sjafirah, "Strategi Komunikasi Dalam Membangun Awareness Wisata Halal Di Kota Bandung," Jurnal Kajian Komunikasi 6, no. 1 (2018): 78-90.

12 Soraya Ratna Pratiwi, Susanne Dida, and Nuryah Asri Sjafirah, "Strategi Komunikasi Dalam Membangun Awareness Wisata Halal Di Kota Bandung," Jurnal Kajian Komunikasi 6, no. 1 (2018): 78-90.

13 Desi Maulida, "Tourism Destination Branding: Analisis Strategi Branding Wisata Halal 'the Light of aceh'(Studi Kasus Pada Dinas Kebudayaan Dan Pariwisata Aceh Tahun 2015-2016),” SOURCE: Jurnal Ilmu Komunikasi 5, no. 1 (2019). 
by stakeholders, namely the government. The government must increase the marketing of halal travel and tourism through various programs and activities, such as massive promotions, socialization, and literacy. ${ }^{14}$

\section{Method}

This paper includes library research, which seeks to explore answers to the problem of halal tourism to empower the people's economy. To explain the problems raised, the author uses a qualitative descriptive approach. Sources of data obtained from various relevant literature, expert opinions and various other supporting information, thus giving birth to a more in-depth elaboration of ideas.

The study of the raised themes, reviewed with the first step, traced information sourced from print and electronic media as well as tourism literature about the development of sharia tourism in the world and Indonesia. Second, collect data in the form of policies on tourism and its development. Third, conduct analysis to describe and interpret the data. In particular, the study of halal tourism as part of the religious practice of Muslims will methodically be described based on the perspective of the Qur'an. Fourth, draw conclusions from the discussions that have been carried out.

\section{Results and Discussion}

\subsection{Tourism According to the Qur'an and Hadith}

The term halal tourism has only been known since 2015 when a World Halal Tourism Summit (WHTS) event was held in Abu Dhabi, UAE. Previously, the world of tourism was only known as a Muslim tour or something like that. In this event, WHTS tries to realize that the market share of halal tourism is very large and needs to be continuously developed. According to the DSN MUI Fatwa, what is meant by halal tourism is various kinds of tourism activities and is supported by various facilities and services provided by the community, businessmen, government and local governments in accordance with sharia principles. ${ }^{15}$

The World Tourism Organization (WTO) refers to tourists as travelers who make short trips. According to this organization, tourists are people who

14 Abrista Devi and Irman Firmansyah, "Developing Halal Travel and Halal Tourism to Promote Economic Growth: A Confirmatory Analysis," Journal of Islamic Monetary Economics and Finance 5, no. 1 (2019): 193-214.

15 Fatwa DSN MUI No.108 Tahun 2016 Tentang Pedoman Penyelenggaraan Pariwisata Berdasarkan Prinsip Syariah, 2016. 
travel to an area or country and stay a minimum of 24 hours or a maximum of 6 months in that place. Chadwick defines tourism as an activity of people outside the environment for a certain period of time and the main tourist destination in addition to education or gaining experience by paying for an activity in the place visited. ${ }^{16}$

Tourism is a complex concept that includes various social, behavioral, economic, political, cultural and environmental considerations. The concept of tourism consists of a series of activities, services and benefits that provide a certain experience to tourists. Buhalis argues that tourist destinations have five important elements, namely attractions, access, facilities, activities, and services related to tourism. ${ }^{17}$

In the view of Islam, firstly, travel is considered as worship, because it is ordered to fulfill the obligations of the pillars of Islam, Hajj and Umrah in certain months are carried out throughout the year to the Baitullah. Second, in the Islamic world view, tourism is also related to the concept of science and learning. This became the greatest journey undertaken at the beginning of Islam with the aim of seeking and spreading knowledge (Q.S. al Taubah: 112). Third, the purpose of tourism in Islam is to learn science and thought. The command to travel on earth appears in several places in the Qur'an (see Surah al-An'am: 1112 and al-Naml: 69-70). Fourth, the greatest purpose of traveling on the Islamic journey is to invite others to God and to convey to mankind the teachings of Islam which were revealed to the Prophet Muhammad. this is the mission of the Prophet and his companions. the companions of the Prophet Muhammad are scattered all over the world, teaching goodness and inviting them to live in truth. concepts developed to achieve these goals. Finally, Islamic tourism also includes travel activities to contemplate the wonders of God's creation and enjoy the beauty of the universe, so that it will make the human soul to develop a strong faith in the oneness of God and will help a person to fulfill his life obligations. ${ }^{18}$

Not only for spiritual benefits, but travel activities are also important for physical benefits. On the other hand, tourism promotion based on religious and historical places that are attractive to international tourists can generate

16 Robin A Chadwick, "Concepts, Definitions and Measures Used in Travel and Tourism Research.," Concepts, definitions and measures used in travel and tourism research. (1987): 47-61.

17 Dimitrios Buhalis, "Marketing the Competitive Destination of the Future," Tourism management 21, no. 1 (2000): 97-116.

18 Aan Jaelani, "Islamic Tourism Development in Cirebon: The Study Heritage Tourism in Islamic Economic Perspective," Journal of Economics Bibliography 3, no. 2 (2016). 
additional income for Muslim countries. In addition, the Organization of the Islamic Conference (OIC) has emphasized to develop tourism activities for its member countries. More Muslim travelers in the Islamic world can lead to better understanding, stimulate collaboration and serve the public interest.

The idea of halal tourism itself appears quite controversial, not only from the point of view of religious authorities but also from the academic side of tourism studies. However, this situation does not have to use a scientific approach in dealing with this problem with some branches of social science, including geographical knowledge can make a special contribution, especially through two perspectives in the form of religious geography and tourism geography. On the other hand, subject to constant evolution as new patterns of behavior and attitudes towards religion, it becomes almost mandatory to clarify some points through interdisciplinary research efforts.

Halal tourism means studying the life of the people of the past (A1-Qur'an, 3: 137); studying the fate of the people of the past (Qur'an 30:42); study how the Prophets were resurrected (Qur'an 16:36); study the lives of the wrongdoers (Qur'an 6:11); think about creation; think about what happened to the wrongdoer; visit a safe and prosperous city (Qur'an 34:11); The Qur'an calls people to travel and learn lessons from what happens to the disbelievers and liars of divine signs.

In general, it can be said that traveling helps people to reach theoretical and practical explanations and to reaffirm their Faith on the Day of Judgment. Traveling helps people learn from the past and prevents tyranny and oppression. Traveling improves sight, hearing, and inner knowledge and saves people from inactivity and indolence.

The basis of the Islamic religion regarding tourism can be seen in several verses of the Koran, namely in Surah Al-Mulk (67):15 and Surah Al-Ankabut (29): 20. Based on these verses, it can be concluded that Allah swt commands humans to travel where they want to go. only what is desired to carry out various affairs and seek sustenance both in business and trade. Humans are also asked to take wisdom and lessons on every journey taken. Allah also commands humans to always think about the world and all its contents, so that humans can understand the nature of His creation and the ultimate purpose of life. ${ }^{19}$

Halal tourism is deeply rooted in Islam because every Muslim should travel (for various reasons, including those that are directly related to Islamic law itself.

19 M. Quraish Shihab, Tafsir Al-Misbah (Pesan, Kesan Dan Keserasian Al-Qur'an), Journal of Chemical Information and Modeling, vol. 53, 2006. 
In the Al-Quran, there are many verses that support travel, namely in Ali-Imran: 137; Al-Imran: 137; Al-Imran: An'am: 11; Al-Nahl: 36; Al-Naml: 69; Al'Ankabut: 20; Ar-Rum: 9 and 42; Saba': 18; Yusuf: 109; Al-Hajj: 46; Fathir: 44; Ghafhir: 82 and 21; Muhammad: 10; Yunus: 22; and Al-Mulk: 15. These verses of the Koran support travel with spiritual, physical, and social goals. ${ }^{20}$

From these verses, it can be learned that a deeper surrender to Allah is possible by directly seeing the beauty and gifts of His creation, and understanding the smallness of humans can glorify the greatness of God. Travel can also improve health and reduce stress, making it possible to worship better. The relationship between tourists (guests) and religion is also emphasized, that Muslims as hosts must provide hospitality to tourists. In Islam, the prayer of safar (travel) is more accepted. So Islam has a great influence on travel and encourages tourism.

Apart from being sourced from the Qur'an, several hadiths indicate an activity called tourism today. For example Ibrahim Abu Isma'il As-Saksaki where the Prophet narrated It was narrated that he said: "I heard Abu Burda accompanying Yazid bin Abi Kabsha on a journey. Yazid used to fast on his way. Abu Burda said to him, "I heard Abu Musa several times say that Allah's Apostle said, When a slave falls ill or travels, then he will get the same reward as he gets for good deeds done at home when in good health." ${ }^{1}$

In a famous hadith, Teoman Duman quotes a hadith of the Prophet Muhammad saying "The reward of deeds depends on the intention and everyone will get the reward according to what he has intentional." 22 Meanwhile, Din asserted that the act of traveling in Islam is considered a roommate activity aimed at placing great emphasis on Islamic motivations such as acting in the way of Allah (fi sabilillah), submitting to Allah's ways (hajj and umrah), awareness of the smallness of humans and the greatness of Allah, encouraging and strengthening the ties of friendship (Muslim brotherhood) and doing business. Muslims are encouraged to achieve physical, social and spiritual goals by traveling. ${ }^{23}$

Another hadith narrated by Abu Shurayh Al-Ka'bi: where Rasulullah saw. said: "Whoever believes in Allah and the Last Day, let him serve his guests generously. The reward of the guest is: Giving him better food for one night

20 Eka Dewi Satriana and Hayyun Durrotul Faridah, "Wisata Halal: Perkembangan, Peluang, Dan Tantangan," Journal of Halal Product and Research (JHPR) 1, no. 2 (2018).

21 Muhammad Al-Bukhari, Sabih Al-Bukhari (Dar Ul-Hadith, 1978).

22 Teoman Duman, "Value of Islamic Tourism Offering: Perspectives from the Turkish Experience," in World Islamic Tourism Forum, 2011, 12-13.

23 Kadir H Din, "Islam and Tourism: Patterns, Issues, and Options," Annals of tourism research 16, no. 4 (1989): 542-563. 
and one day and a guest being entertained with food for three days, and what is slaughtered outside of that, is considered a charity. And it is not lawful for a guest to stay with his host for such a long time that it puts him in a critical position." ${ }^{24}$

Thus, the practice of halal tourism has been carried out since the time of the Prophet Muhammad and his companions for social and spiritual interests. In terms of Islamic law, the prophet Muhammad. also explains the existence of relief in prayer by collecting or summarizing the number of rak'ahs of prayer when someone is traveling far with the aim of worship. ${ }^{25}$ Thus, the Qur'an and hadith have provided an explanation of Islamic rules regarding the journey of sharia through the provisions of Islamic law.

\subsection{Economic Empowerment of People from the Perspective of the Qur'an}

The Qur'an views that the economic weakness of the people (poverty) is a social problem that must be eradicated. Even dangerous diseases that must be treated. Islam does not support the theory of individual behavior which views that the poor are the poor themselves, not society, the government or the rich. But Islam also disagrees with structural theory which only focuses on the structural causes of the problem of poverty. ${ }^{26}$

On the one hand, Islam recognizes and protects legitimate individual property. Everyone who acquires property legally, he has full power over the property. Islam recognizes differences in obtaining wealth and views it as something natural in accordance with the differences in the skills and abilities of each person and as an incentive for someone to work and try seriously. It's just that these differences must be in the context of controlled and just differences. Differences that encourage morale and productivity, give birth to harmony and complementarity, not contradictions and conflicts.

On the other hand, Islam demands an equitable distribution of wealth ensure a decent standard of living for everyone. Islam argues that the economic problem lies in the practice of human injustice in the distribution of wealth, not in the depletion of natural wealth compared to human needs. ${ }^{27}$

${ }^{24}$ Muhammad Muhsin Khan, "Sahih Bukhari," Sahih Bukhari (1985).

25 Hatem El-Gohary, "Halal Tourism, Is It Really Halal?," Tourism Management Perspectives 19 (2016): 124-130.

26 Yusuf Qardhawi, Muaassasah Al-Risālah (Beirut: Mu’assasah al-Risālah, 1998).

27 Rahmat Gunawijaya, "Kebutuhan Manusia Dalam Pandangan Ekonomi Kapitalis Dan Ekonomi Islam,” Jurnal Al-Maslahah 13, no. 1 (2017). 
From this it appears that the issue of how to free the economically weak people and how to empower their economic life is closely related to the problem of the use and distribution of wealth. Therefore, efforts to liberate and empower the underprivileged must first look at the provisions of the Qur'an regarding the use and distribution of property.

From the verses of the Qur'an that talk about property (mal, amwal), in general two provisions of the Qur'an can be drawn regarding the use and distribution of property. The first is in the form of orders and suggestions and the second is a prohibition. Of these two provisions, there are several steps taken by the Qur'an in alleviating poverty and empowering the weak, namely the order to work, the command to feed, the command to give alms, the order to issue zakat, the distribution of ghanimah and fa' $i$, the determination of inheritance law, prohibition of usury, prohibition of monopoly (ihtikar) and hoarding of wealth (iktinaz).

This work order is related to the position and purpose of attendance humans on this earth have two functions, namely as servants of Allah and as vicegerents of Allah. As servants of Allah (Abdullah) humans are tasked with serving (worshiping Allah) (Surah al-Dzariyat [51]: 56). Serving (worshipping) God can be done by humans through two forms of worship: special worship (mahdhah worship) and general worship (ghair mahdhah worship). Special worship is all forms of worship whose rules and procedures have been determined by Allah, such as prayer, fasting, zakat and hajj. While public worship is all forms of pious deeds whose rules and procedures are not specifically determined by religion. All human activities and activities in any field, including work, are actually carried out in the context of devotion and worship to Him (Surah Al-An'am [6]:162). ${ }^{28}$

As the vicegerent of Allah on earth (Surah al-Baqarah [2]:30) humans are representatives of Allah and His power to take care of the earth and all its contents and prosper it (Surah Hud [11]:61). Prospering the earth means prospering life in this world. For this reason, humans are obliged to work and strive, do good deeds (do good that is beneficial) for themselves, society and their environment and maintain the balance of nature and the earth they inhabit, in accordance with the guidance given by Allah through religion. ${ }^{29}$

${ }_{28}$ Muhammad Fuadi Abdul Baqi, Al-Mujjam Al-Mufahras Li Alfadh Al-Quran (Kairo: Darul Hadits, 2007).

${ }^{29}$ Abi Ja'far Muhammad Ibn Jarir Al-Thabari, Tafsir Al-Thabari (Beirut: Darul Fikri, 1978). 
The verses of the Qur'an in the letter (Surah Al-Maun [107]:3) which discuss poverty encourage Muslims to become people who care and share with the poor, including the poor, by providing first aid to them in their lives. the form of an order to provide basic food to the poor in order to maintain their survival. ${ }^{30}$

Pearse and Stiefel stated that the process of empowerment contains two tendencies, primary and secondary. The primary tendency, the empowerment process emphasizes the process of giving or transferring some power, strength or ability to the community so that individuals become more empowered. While the secondary tendency sees empowerment as a process of stimulating, encouraging or motivating individuals to have the ability or empowerment to determine what their choices are. ${ }^{31}$

The concept of empowerment is the result of an interactive process at the ideological and practical levels. At the ideological level, it is the result of the interaction between top-down and bottom-up concepts between growth strategy and people-centered strategy. ${ }^{32}$

While at the practical level, the interactive process occurs through the struggle between autonomy. Therefore, the concept of empowerment includes the notion of community development and community-based development. ${ }^{33}$ The underprivileged is a complex and multidimensional social problem. Facing

${ }_{30}$ Muhammad Nawawi Al-Jawi, Marah Labid Likasyfi Ma’na Qur'anim Majid (Semarang: Toha Putra, n.d.).

31 A.M.W. Pranarka, Onny S. Prijono, and A.M.W. Pranarka, Pemberdayaan Konsep, Kebijakan Dan Implementasi/ Penyunting, Centre for Strategicand International Studies (CSIS), 1996, 1996.

32 I Wayan Rusastra and NFN Erwidodo, "Growth, Equity and Environmental Aspects of Agricultural Development in Indonesia," Forum penelitian Agro Ekonomi 16, no. 1 (2016): 32.i.e. maintaining economic growth, promoting equity and protecting the environment. Price support policy is essential for enhancing technological adoption, increasing output and farmer income. In addition, dynamic institutional and vision of agricultural development, efficiency improvement and technological generation played an important role in the production strategy. Off-Java wetland rice farmers have greater opportunities to gain production through enhanced technical or economic efficiency by improving their managerial skills. In contrast, for dry land rice and secondary crops' farmers, only research and technological breakthrough can solve the low productivity problems and increase farmers' income. Poverty alleviation requires comprehensive efforts that should be conducted in a simultaneous manner. However, the monetary and economic crisis recently faced by the government, provides strong reasons to focus attention on agriculture and rural development availing the best chance to stimulate sustainable growth that address food security, poverty and income distribution concerns. The government has implemented some programs dealing with sustainable agricultural development. Some of those programs were successfully implemented such as integrated pest management (IPM

33 Muhammad Istan, "Pengentasan Kemiskinan Melalui Pemberdayaan Ekonomi Umat Menurut Persfektif Islam,” Al-Falah: Journal of Islamic Economics 2, no. 1 (2017): 81-99. 
these acute and chronic social problems, the Qur'an offers several principles in empowering the weak people as follows:

First, the principle of ta'awun, namely the principle of cooperation and synergy between various parties, namely the government, zakat institutions, scholars, Islamic organizations and various community groups in general. This principle is based on the word of Allah SWT as follows: "And help you in (doing) goodness and piety, and do not help in committing sins and transgressions. And fear Allah, indeed Allah is severe in punishment" (Surat al-Ma'idah [5]:2).

Poverty alleviation is not a monopoly of the government with its various sectoral departments. However, the response is a multidimensional problem that is the responsibility of all relevant parties. With various limitations, both in terms of management, organization and finance, the government will not be able to be the sole player in poverty alleviation.

Poverty alleviation must be carried out thoroughly across sectors and regions, involving cross-actor forums. Therefore, cooperation and synergy in poverty alleviation with the empowerment of the people absolutely must be done. This form of ta'awun includes institutions, management, finance, human resources, programs, methodologies, and policies so as to give birth to integrated forces in overcoming poverty.

Second, the shura principle, namely the principle of deliberation between the government and parties related to the issue of empowering the needy and poor in a program that cares for the problem of poverty by identifying the problems that cause poverty and formulating sustainable countermeasures. The principle of shura is mainly related to ways to identify problems correctly, find accurate data, and give birth to quick steps.

Poverty alleviation without the above social capital will be fragile if it is carried out without adhering to the shura principle. This shura principle means acknowledgment and appreciation for the existence of thoughts, ideas, wills, experiences of every component in the community. With the shura mechanism, it means expanding the level of involvement and participation of every component of society in every stage of economic empowerment of the people.

\subsection{Halal Tourism as a Basis for Empowerment of the People's Economy}

Halal tourism is broader than religious tourism, namely tourism that based on Islamic sharia values. As recommended by the World Tourism Organization 
(WTO), sharia tourism consumers are not only Muslims but also non-Muslims who want to enjoy local wisdom. ${ }^{34}$

Halal tourism is a form of culture-based tourism that puts the values and norms of Islamic law as the basic foundation. With the largest Muslim population in the world, Indonesia is the largest market for the halal tourism industry in the world and tourism business players in Indonesia should be aware of this because the sustainable development of halal tourism will provide a significant economic contribution for all actors involved in it.

The concept of halal tourism is a process of integrating Islamic values into all aspects of tourism activities. The value of Islamic law as a belief and belief held by Muslims is the basic reference in building tourism activities. Halal tourism considers the basic values of Muslims in the presentation starting from accommodation, restaurants which always refer to Islamic norms. ${ }^{35}$

Halal tourism is the actualization of the Islamic concept where the values of halal and haram are the main benchmarks, this means that all aspects of tourism activities cannot be separated from halal certification which must be a reference for every tourism actor. ${ }^{36}$ The concept of halal tourism can also be interpreted as a tourism activity based on worship and da'wah when Muslim tourists can travel and glorify the results of Allah's creation (taking nature) by continuing to carry out the obligatory prayers five times a day and all of this is well facilitated and away from everything. which is forbidden by him. ${ }^{37}$

The basics of halal tourism include components such as: halal food, halal transportation, halal hotels, halal logistics, Islamic finance, Islamic travel packages, and halal spas. According to Chookaew, there are eight standard factors for measuring sharia tourism in terms of administration and management for all tourists, which can be a separate characteristic, namely: ${ }^{38}$ 1) Service to tourists must be in accordance with Muslim principles as a whole; 2) Guides and staff must be disciplined and respect Islamic principles; 3) Regulate all activities so

${ }^{34}$ Mohamed Battour et al., "Islamic Tourism: An Empirical Examination of Travel Motivation and Satisfaction in Malaysia," Current Issues in Tourism 20, no. 1 (2017): 50-67.

35 Alexander Preko et al., "Islamic Tourism: Travel Motivations, Satisfaction and Word of Mouth, Ghana," Journal of Islamic Marketing (2020).

36 Lee Shi Yan et al., "Halal Tourism: A New World for Tourism Industry," International Journal of Asian Social Science 7, no. 8 (2017): 643-657.

37 Ahmad Jamal, Kevin Griffin, and Razaq Raj, Islamic Tourism: Management of Travel Destinations (CABI, 2018).

38 Sureerat Chookaew et al., "Increasing Halal Tourism Potential at Andaman Gulf in Thailand for Muslim Country," Journal of Economics, Business and Management 3, no. 7 (2015): 739-741. 
that they do not conflict with Islamic principles; 4) Buildings must conform to Islamic principles; 5) Restaurants must comply with international halal service standards; 6) Transportation services must have a security protection system; 7) There are places provided for all Muslim tourists to carry out religious activities; 8) Traveling to places that are not against Islamic principles.

Global Muslim Travel Index 2019, there are three groups of halal tourism criteria described; (1), destinations need to have halal food, facilities for places of worship, facilities for self-cleaning and no elements of Islamic phobia (meaning that there are no anti-Islamic people in the surrounding community). (2) Tourist destinations should have a good social impact on the surrounding community, with the existence of these destinations having a positive religious influence on the surrounding community. In the month of Ramadan the destination area has religious activities and a fun activity experience for local Muslims. (3) Halal tourism destinations should have a privacy area (for example, there is a separation between women's and men's areas in the swimming pool) and no non-halal services such as not selling liquor, pornographic activities and immorality. ${ }^{39}$

In order for tourism development in a tourist destination to achieve optimal results, it is necessary to set targets and development directions. Tourism development according to Pearce is defined as an effort to complete or improve the facilities and services needed by the community. The development of tourism both in local/regional/national tourist destinations in a country is closely related to economic development in the region or country.

The development of the tourism sector is carried out by involving all levels of society as service providers/tourism industries as well as tourism actors so that tourism can become the property of the community so that the benefits of its sustainability are more guaranteed and must pay attention to religious values, traditions and other norms that live and are adhered to among the local communities. ongoing tourism activities.

Several things need to be considered and determined in the development of a tourist attraction, namely: 1) tourist attractions, promotion and marketing, 3) tourism markets, 4) transportation. There are five basic elements as a recipe for increasing tourist visits in the development of halal tourist destinations, namely 1) attractions, 2) accessibility, 3) amenities, 4) image and 5) price. ${ }^{40}$

\footnotetext{
39 Aam Bastaman, Lombok Islamic Tourism Attractiveness: Non-Moslem Perspectives, Int.J Sup. Chain. Mgt, vol. 7, 2018.

40 Satriana and Faridah, "Wisata Halal: Perkembangan, Peluang, Dan Tantangan."
} 
Tourism is one part of national development which has the aim of expanding and equalizing business opportunities, employment and people's welfare. Thus, development in the field of tourism has the ultimate goal of increasing people's income which has an impact on increasing community welfare.

Tourism is one part of national development which has the aim of expanding and equalizing business opportunities, employment and people's welfare. Thus, development in the field of tourism has the ultimate goal of increasing people's income which has an impact on increasing community welfare.

According to Saefullah (2000), tourism will have an impact on the community's economy, namely tourism will generate income for the local community. This income is generated from transactions between tourists and hosts in the form of spending such as tourist transactions at hotels, restaurants, tour guides, travel agencies, gift shops, tourist attractions, transportation, communication sector, handicraft industry, agricultural sector. Another impact of tourism development is the creation of jobs.

With the existence of tourist destinations, it can open up job opportunities with various types of creative work so that it can accommodate quite a lot of workers. There are business opportunities for food, souvenirs, rental of beach mats, tour guides, reflexology, the proliferation of transportation entrepreneurs, tourist bureaus, lodging and so on.

Tourism also has an impact on opening up investment opportunities. Tourism development will open up opportunities for investors to invest or open businesses in tourist areas and this will have an impact on increasing the economy of the local community. Tourism development will also encourage entrepreneurial activity.

The needs of tourists when visiting tourist destinations will encourage the community to provide for the needs of these tourists by opening a business related to the needs of tourists. With an increase in people's income from the tourism industry, the economic structure and welfare of the community will be better. With the aim of further improving people's welfare from an economic perspective, the government can take steps mobilize the existing real sectors by empowering the community.

The existence of a halal tourism program can provide an increase in income for tourism actors. For example, souvenir entrepreneurs who used to sell clothes at home, can then sell songkets, clothes, souvenirs, pearl souvenirs in hotels and 
halal tourist destinations. So that the income earned is more than before and can send their children to school.

The development of the halal tourism sector greatly influences the income of transportation service providers. With so many foreign tourists coming, it has a good impact on the economy of the surrounding community. Business opportunities are not only from transportation, it can also be from halal culinary, so that it can open up opportunities to open halal restaurants. For tour guides, they can take foreign tourists to halal tourist destinations, thereby increasing their income.

For hotel employees, when the hotel is crowded, they will get more monthly incentives. The more revenue each month is collected, the employees will get a lot of incentives. But if the hotel is deserted, the less incentive they receive.

From some of the descriptions above, it can be seen that the existence of a halal tourism program has provided an increase in income for tourism actors. With an increase in tourists who come, the income and welfare of the community will increase.

The development of the concept of halal tourism to create comfort for visiting tourists, of course, for the welfare of the community. Foster good relations between tourists and the local community. The more tourists who visit, the income of the community will increase. Community welfare is seen from the income earned. In addition, regional development aims to enable the surrounding community to generate income or increase existing income.

Since tourism has become the full attention of the local government, people who initially did not have a job can get a job by selling around tourist areas or creating handicrafts typical of the area as souvenirs traveler. Welfare is part of the indicators to measure regional development success rate. Regional development through tourism sector which is quite promising because every year it experiences improvement, giving hope for the welfare of people's lives. ${ }^{41}$

With the increase in tourist arrivals, it has a positive impact on the community. This certainly has very positive implications for regional development, one of which is the welfare of the community. In addition, the implications felt by the community for halal tourism are not only in tourist locations but in several sectors, one of which is plantations where the plantations produce coconuts which are

41 Fitratun Ramadhany and Ahmad Ajib Ridlwan, "Implikasi Pariwisata Syariah Terhadap Peningkatan Pendapatan Dan Kesejahteraan Masyarakat,” Muslim Heritage 3, no. 1 (2018): 157-176. 
mostly sold at tourist sites, or the creativity of people who use coconut shells to produce handicrafts. hands that become souvenirs for tourists.

\section{Conclusion}

Efforts to empower the people's economy can be done by developing halal tourism. Halal tourism is in line with the commands of the Qur'an and AlHadith. The spirit of halal travel at its peak makes humans more polite and contemplative of the power of God. It makes people more grateful and closer to God. The large number of global Muslim tourists visiting Indonesia, makes halal tourism potential to be one of the sectors driving Indonesia's halal industry. There are no less than 140 million Muslim tourists with online shopping of USD 35 billion every year. This is a challenge as well as an opportunity to make halal tourism a national tourism industry and a means of empowering the people's economy. Halal tourism development can be used as a means to empower the people's economy. Opening up greater job opportunities thereby reducing unemployment. Improving the welfare of the people by opening up business and job opportunities. Can increase the income of the people so that it has an impact on increasing the ability of the community to be able to live more prosperously.

\section{References}

Al-Bukhari, Muhammad. Sabih Al-Bukhari. Dar U1-Hadith, 1978.

Al-Jawi, Muhammad Nawawi. Marah Labid Likasyfi Ma’na Qur'anim Majid. Semarang: Toha Putra, n.d.

Al-Thabari, Abi Ja'far Muhammad Ibn Jarir. Tafsir Al-Thabari. Beirut: Darul Fikri, 1978.

Aripin Marpaung. "Increasing Economic Empowerment of the People through Productive Waqf." Britain International of Humanities and Social Sciences (BIoHS) Journal 2, no. 3 (2020): 632-642.

Baqi, Muhammad Fuadi Abdul. Al-Mu'jam Al-Mufahras Li Alfadh Al-Quran. Kairo: Darul Hadits, 2007.

Bastaman, Aam. Lombok Islamic Tourism Attractiveness: Non-Moslem Perspectives. Int. J Sup. Chain. Mgt. Vol. 7, 2018.

Battour, Mohamed, Mohd Nazari Ismail, Moustafa Battor, and Muhammad Awais. "Islamic Tourism: An Empirical Examination of Travel Motivation 
and Satisfaction in Malaysia." Current Issues in Tourism 20, no. 1 (2017): $50-67$.

Buhalis, Dimitrios. "Marketing the Competitive Destination of the Future." Tourism management 21, no. 1 (2000): 97-116.

Chadwick, Robin A. "Concepts, Definitions and Measures Used in Travel and Tourism Research." Concepts, definitions and measures used in travel and tourism research. (1987): 47-61.

Chookaew, Sureerat, Oraphan chanin, Jirapa Charatarawat, Pingpis Sriprasert, and Sudarat Nimpaya. "Increasing Halal Tourism Potential at Andaman Gulf in Thailand for Muslim Country." Journal of Economics, Business and Management 3, no. 7 (2015): 739-741.

Collins-Kreiner, Noga, and Geoffrey Wall. "Tourism and Religion: Spiritual Journeys and Their Consequences." In The Changing World Religion Map: Sacred Places, Identities, Practices and Politics, 689-707, 2015.

Devi, Abrista, and Irman Firmansyah. "Developing Halal Travel and Halal Tourism to Promote Economic Growth: A Confirmatory Analysis." Journal of Islamic Monetary Economics and Finance 5, no. 1 (2019): 193-214.

Din, Kadir H. "Islam and Tourism: Patterns, Issues, and Options." Annals of tourism research 16, no. 4 (1989): 542-563.

Duman, Teoman. "Value of Islamic Tourism Offering: Perspectives from the Turkish Experience." In World Islamic Tourism Forum, 12-13, 2011.

El-Gohary, Hatem. "Halal Tourism, Is It Really Halal?" Tourism Management Perspectives 19 (2016): 124-130.

Gunawijaya, Rahmat. "Kebutuhan Manusia Dalam Pandangan Ekonomi Kapitalis Dan Ekonomi Islam.” Jurnal Al-Maslahab 13, no. 1 (2017).

Istan, Muhammad. "Pengentasan Kemiskinan Melalui Pemberdayaan Ekonomi Umat Menurut Persfektif Islam." Al-Falah: Journal of Islamic Economics 2, no. 1 (2017): 81-99.

Jaelani, Aan. "Islamic Tourism Development in Cirebon: The Study Heritage Tourism in Islamic Economic Perspective."Journal of Economics Bibliography 3, no. 2 (2016).

Jamal, Ahmad, Kevin Griffin, and Razaq Raj. Islamic Tourism: Management of Travel Destinations. CABI, 2018.

Jia, Xiong, and Zhang Chaozhi. "Halal Tourism': Is It the Same Trend in NonIslamic Destinations with Islamic Destinations?" Asia Pacific Journal of Tourism Research 25, no. 2 (2020): 189-204. 
Khan, Muhammad Muhsin. "Sahih Bukhari." Sabib Bukhari (1985).

Mannaa, Maryam Taha. "Halal Food in the Tourist Destination and Its Importance for Muslim Travellers." Current Issues in Tourism 23, no. 17 (2020): 2195-2206.

Mariska, Dini, and Eric Jacob Shelton. "Prophet or Profit? Emotional Reflections on Indonesian Tourism.” 271-288, 2018.

Maulida, Desi. “Tourism Destination Branding: Analisis Strategi Branding Wisata Halal 'the Light of aceh'(Studi Kasus Pada Dinas Kebudayaan Dan Pariwisata Aceh Tahun 2015-2016)." SOURCE: Jurnal Ilmu Komunikasi 5, no. 1 (2019).

Peristiwo, Hadi. "Indonesian and Malaysian Potential for a Halal Tourism Industry." African Journal of Hospitality, Tourism and Leisure 9, no. 1 (2020): $1-16$.

Pranarka, A.M.W., Onny S. Prijono, and A.M.W. Pranarka. Pemberdayaan Konsep, Kebijakan Dan Implementasi/ Penyunting. Centre for Strategicand International Studies (CSIS), 1996, 1996.

Pratiwi, Soraya Ratna, Susanne Dida, and Nuryah Asri Sjafirah. "Strategi Komunikasi Dalam Membangun Awareness Wisata Halal Di Kota Bandung." Jurnal Kajian Komunikasi 6, no. 1 (2018): 78-90.

Preko, Alexander, Iddrisu Mohammed, Theophilus Francis Gyepi-Garbrah, and Azizbek Allaberganov. "Islamic Tourism: Travel Motivations, Satisfaction and Word of Mouth, Ghana.” Journal of Islamic Marketing (2020).

Qardhawi, Yusuf. Muaassasah Al-Risālah. Beirut: Mu'assasah al-Risālah, 1998.

Rahmawati Sushanti, Ima, Mustamin H. Idris, Baiq Harly Widayanti, Fariz Primadi Hirsan, Lukman Abdullah, and Intan Savia Fitri. "An Assessment of Local Economic Empowerment Using Halal Tourism Approach: A Case from Sembalun District East Lombok, Indonesia." IJECA (International Journal of Education and Curriculum Application) (2018): 112.

Ramadhany, Fitratun, and Ahmad Ajib Ridlwan. "Implikasi Pariwisata Syariah Terhadap Peningkatan Pendapatan Dan Kesejahteraan Masyarakat.” Muslim Heritage 3, no. 1 (2018): 157-176.

Ropiah, Eva Siti. "Wisata Halal: Potensi Ekonomi Baru Industri Pariwisata Di Kabupaten Cirebon." Inklusif (Jurnal Pengkajian Penelitian Ekonomi Dan Hukum Islam) 3, no. 2 (2018): 166-183. 
Rusastra, I Wayan, and NFN Erwidodo. "Growth, Equity and Environmental Aspects of Agricultural Development in Indonesia." Forum penelitian Agro Ekonomi 16, no. 1 (2016): 32.

Satriana,Eka Dewi, and Hayyun DurrotulFaridah."Wisata Halal: Perkembangan, Peluang, Dan Tantangan.” Journal of Halal Product and Research (JHPR) 1, no. 2 (2018).

Shihab, M. Quraish. Tafsir Al-Misbah (Pesan, Kesan Dan Keserasian Al-Qur'an). Journal of Chemical Information and Modeling. Vol. 53, 2006.

Timothy, Dallen J, and Daniel H Olsen. Tourism, Religion and Spiritual Journeys. Vol. 4. Routledge London, 2006.

Vargas-Sánchez, Alfonso, and María Moral-Moral. "Halal Tourism, Where Are We?" 211-232, 2018.

Yan, Lee Shi, Nor Amirah Zahari, Aimi Sara Ismail, and Norhidayu Muhamad Zain. "Halal Tourism: A New World for Tourism Industry." International Journal of Asian Social Science 7, no. 8 (2017): 643-657.

Fatwa DSN MUI No.108 Tahun 2016 Tentang Pedoman Penyelenggaraan Pariwisata Berdasarkan Prinsip Syariah, 2016. 
